\title{
DAMPAK DAN MODEL BARU PEMERINTAHAN TERBELAH PASCA PEMILIHAN GUBERNUR KALIMANTAN BARAT TAHUN 2018
}

\author{
Andi Syarif T. U. W'1, Muh. Ilham², Sampara Lukman³, Ella Wargadinata ${ }^{4}$ \\ 1,2,3,4 Institut Pemerintahan Dalam Negeri (IPDN) \\ Email: pt.dharmamuhibah@gmail.com
}

\begin{abstract}
Abstrak
Pada tahun 2000, Pemerintah Indonesia mengambil langkah berani dengan menerapkan kebijakan desentralisasi yang sangat radikal dengan menyerahkan kewenangan yang luas kepada pemerintah daerah. Konsep pemerintahan terbelah (divided government) merupakan hal baru yang terjadi dalam sistim pemerintahan di Indonesia. Artikel ini mengkaji pengaruh pemilihan Gubernur di Kalimantan Barat pada tahun 2018 dan menilai paradigma saat ini untuk pemerintahan yang terbelah. Penelitian ini menggunakan metode deskriptif kualitatif, yang memberikan analisis lengkap dan analisis bukti yang ditemukan. Hasil penelitian menunjukkan bahwa pemerintahan terbelah dapat memberikan dampak terhadap hambatan politik dan hambatan birokrasi pasca Pemilihan Gubernur Kalimantan Barat 2018. Penelitian juga menemukan dan memperkernalkan metode baru dalam penyelenggaran Pemerintahan terbelah yaitu melalui ANDI sebagai implikasi teori.
\end{abstract}

Kata Kunci: Kepemimpinan Terbelah, Komunikasi Politik, Demokrasi, Pemilihan Gubernur.

\section{Abstract}

In 2000, the Government of Indonesia took a bold step by adopting a very radical policy of decentralization by devolving broad powers to local governments. The concept of divided government is a new thing that is happening in the government system in Indonesia. This article examines the impact of the governor election in West Kalimantan in 2018 and assesses the current paradigm for divided governance. This study uses a qualitative descriptive method, which provides a complete analysis and analysis of the evidence found. The results show that divided government can have an impact on political and bureaucratic obstacles after the 2018 West Kalimantan Governor Election. The study also found and introduced new methods of implementing split government, namely through ANDI as theoretical implications.

Keywords: Split Leadership, Political Communication, Democracy, Governor Election.

\section{A. PENDAHULUAN}

Pada tahun 2000, Pemerintah Indonesia mengambil langkah berani dengan menerapkan kebijakan desentralisasi yang sangat radikal dengan menyerahkan kewenangan yang luas kepada pemerintah daerah (Dewanta, 2016). Para ahli dan banyak referensi menyebutnya sebagai big bang decentralization. Kebijakan ini disetarakan oleh pengamat asing sebagai ledakan bintang karena berisi langkah-langkah yang mengubah wajah Pemerintah Indonesia secara fundamental (Hofman dkk., 2002).

Dibalik kendala dan permasalahan yang dihadapi oleh Pemerintah dalam menjalanan kebijakan ini, Pemerintah Indonesia memiliki komitmen untuk tetap memberikan kewenangan luas kepada pemerintah daerah dalam menjelankan pemerintah di tingkat lokal. 
Desentralisasi berhasil menciptakan daerah-daerah yang memiliki berbagai inovasi dan mampu meningkatkan kesejahteraan di daerah-daerah otonom (Sulistiowati, 2014). Desentralisasi secara signifikan mempengaruhi kualitas pelayanan publik di daerah lebih baik. Pasca kebijakan desentralisasi dilaksanakan, terlihat pembangunna infrastruktur di daerah semakin baik dan berkembang (Maryam, 2017). Pemerintah Indonesia mengakui perbedaan memiliki penampilan ekonomi yang baik, serta sukses mendorong pemerintah daerah untuk lebih kreatif dan inovatif (Prasojo, 2003).

Ketika pemilihan langsung dilaksanakan di Indonesia, sistem penyelenggaraan Pemerintahan mengalami perubahan besar. Pemilihan Presiden-Wakil Presiden di tingkat nasional, pemilihan kepala daerah, termasuk gubernur, bupati, dan walikota, serta pemilihan perwakilan legislatif di tingkat pemerintah daerah dilakukan dengan model suara terbanyak, semuanya memiliki konsekuensi yang besar bagi pemerintahan (Pardede, 2014). Pemilihan Kepala Daerah dan Wakil Kepala Daerah secara langsung sangat penting untuk tahap desentralisasi dalam pemerintahan karena akan memberikan peran yang sangat strategis kepada Kepala Daerah dan Wakil Kepala Daerah dalam meningkatkan kehidupan bangsa, keadilan, demokrasi, kesehatan masyarakat, dan menjamin hubungan yang positif. hidup berdampingan dengan Pemerintah Pusat dan Pemerintah Daerah lainnya dalam rangka melindungi martabat Negara Kesatuan Republik Indonesia (Setiawan dkk., 2018).

Oleh sebab fungsi check and balance dikembalikan ke lembaga legislatif. Dampak pengembalian kewenangan ini menjadikan lembaga eksekutif-legislatif memiliki posisi yang sejajar (Sulaiman, 2020). Kesetimbangan antara eksekutif-legislatif menuntut kedua lembaga ini untuk bisa melakukan kolaborasi dan menjalankan roda pemerintahan dengan benar agar mandat yang diberikan rakyat melalui pemilu dapat dikembalikan kepada rakyat dengan menghasilkan kebijakan yang pro-rakyat dengan menghapus labelling konstituen maupun partai politik pendukung maupun lawan (Solihah \& Witianti, 2016).

Permasalahan akan muncul ketika eksekutif terpilih bukan berasal dari partai mayoritas di lembaga legislatif. Pertanyaan yang paling sederhana yang muncul adalah 'bagaimana eksekutif bisa meloloskan RUU ketika pembahas berasal dari partai nonpendukung?' atau 'apakah proses pembahasan RUU yang diusulkan oleh eksekutif akan terganjal ketika dibahas di legislatif yang berisi anggota dari partai lawan?'. Konsep perbedaan partai pengusung eksekutif dan partai mayoritas di legislatif inilah yang dikenal sebagai pemerintahan terbelah/ Divided Government (Elgie, 2001). Konsep ini memiliki gaung yang kuat di Negara Amerika Serikat yang berusaha melakukan eksplorasi tentang dinamika maupun dampak yang terjadi ketika Presiden terpilih berasal dari partai minoritas di senat (Howell dkk, 2000). Gejala pemerintahan terbelah, atau dikatakan juga sebagai pemerintahan minoritas, ketika kepala daerah berasal dari partai minoritas dan legslatif diisi oleh partai politik non-pendukung, terjadi juga di Indonesia. Penelitian Pilkada hasil Undang Undang Nomor 32 tahun 2004 memperlihatkan sebanyak 56,3\% Kepala Daerah terpilih mendapatkan suara terbanyak namun tidak mendapat dukungan politik di lembaga legislatif (Permata, 2008).

Gejala pemerintahan terbelah terjadi pada pemilihan Guberur Kalimantan Barat tahun 2018. Pasangan Sutarmidji-Ria Norsan didukung oleh koalisi Golkar-Nasdem, Hanura, PKB dan PKS hanya memiliki 21 kursi dengan dukungan 32,3\% dari total kursi di DPRD. Secara mengejutkan pasangan ini memenangkan pilgub Kalbar 2018 dengan megalahkan pasangan 
Karolin-Gidot yang didukung oleh mayoritas suara DPRD, sebanyak 41,5\%. Pasangan kuat ini diusung oleh Partai PDI-P, Demokrat dan PKPI. Rapat Pleno Rapat Pleno Rapat Umum Gubernur Kalbar 2018 menunjukkan Sutarmidji dan Ria Norsan memenangkan Pilgub Kalbar dengan perolehan suara 51,55\%, disusul calon lawan 2 Caroline Quito (Karolin-Gidot) 1.081.876 suara atau 41,79\%, dan kandidat terakhir adalah 172.151 suara untuk 1 MiltonBoyman, atau $6,65 \%$.

Berbeda dengan penelitian divided government yang banyak dikaji di Amerika Serikat, sebaliknya belum banyak kajian di Indonesia yang membahas bagaimana hubungan yang dibangun antara kepala daerah terpilih dari jalur indepeden maupun dukungan politik minoritas ketika menjalankan roda pemerintahan. Penelitian Saraswati (2010) atas pemerintahan di Kabupaten Garut menyiratkan bahwa perlu komunikasi yang intens bagi kepala daerah yang tidak didukung oleh partai politik, bahkan bagi kepala daerah yang berasal dari jalur perseorang. Vermonte (2015) menyatakan bahwa kemenangan Jokowi pada Pilpres 2014 mengundang debat tetang gejala pemerintahan terbelah, mengingat partai pendukung bukanlah partai mayoritas di lembaga legislatif.

Dari uraian tersebut diatas penulis bermaksud membuat kajian tentang dampak dan model baru pemerintahan terbelah pasca pemilihan gubernur Kalimantan Barat Tahun 2018. Maksud kajian ini untuk memahami dampak yang terjadi pada pemerintahan di Kalimantan Barat apabila kepala daerah berasal dari bukan partai pendukung mayoritas dan menemukan model baru dalam penyelenggaraan pemerintahan terbelah di Kalimantan Barat.

\section{B. METODE}

Pendekatan kualitatif analitik digunakan dalam penelitian ini untuk menyajikan buktibukti yang ditemukan melalui investigasi mendalam. Analisis kualitatif adalah teknik untuk memfasilitasi dan memahami konteks seseorang atau komunitas yang terkena dampak masalah sosial atau kemanusiaan. Banyak kegiatan kritis dimasukkan dalam analisis kualitatif, termasuk mengembangkan pertanyaan dan metode, mengumpulkan data yang relevan dari informan, meringkas dan menafsirkan data mulai dari subjek khusus hingga luas, dan menjelaskan pentingnya data (Creswell, 2002).

Denzin \& Lincoln, (2005) menyebutkan metode kualitatif merupakan sebuah aktivitas yang membuat peneliti merepresentasikan sebuah data seperti catatan lapangan, wawancara, percakapan, gambar, suara, maupun memo sebagai bagian dalam menginterpretasikan sebuah fenomena yang diteliti. Wawancara mendalam menjadi strategi utama dalam metode kualitatif. Wawancara mendalam merupakan pertanyaan dan respon terbuka dari narasumber untuk mendapatkan data yang diinginkan, terutama pada penjelasan terhadap fenomenafenomena yang ingin diteliti. Salah satunya ialah wawancara terpadu, yaitu dengan topik dijabarkan terlebih dahulu, dan peneliti bebas memilih dan menyusun rangkaian kalimat selama wawancara.

\section{HASIL DAN PEMBAHASAN}

\section{Dampak Pemerintahan Terbelah}

Adanya pemerintahan terbelah (Divided Government) yakni dimana kepala daerah berasal dari partai minoritas seperti yang terjadi di Kalimantan Barat telah memberikan 
dampak pada jalan pemenrintahan di provinsi terebut. Dampak tersebut dapat berupa hambatan-hambatan yang terjadi baik berupa hambatan politik dan hambatan birokrasi.

a. Hambatan Politik

Politik berhubungan dengan kepentingan. Namun, motif tidak terkait dengan politik. Politik masih tentang prioritas, dan politik terkait erat dengan kepentingan (Fuadi, 2020). Politik dan keinginan, di sisi lain, berbeda. Wajar jika kita berbicara politik, itu akan menarik perhatian orang. Politik terkait erat dengan kepentingan yang disepakati bersama. Setiap pilihan dalam politik biasanya dimotivasi oleh kepentingan pribadi. Menurut filsafat klasik Aristoteles, politik dilakukan oleh masyarakat dalam upaya memahami kepentingan bersama. Ungkapan "kepentingan bersama" sangat penting dalam konsep ini. Menurut Aristoteles, politik adalah keinginan yang mirip dengan keinginan untuk mencapai tujuan bersama (Dewantara, 2017). Dengan kata lain, kekhawatiran ini disebut sebagai masalah nasional. Untuk memastikan kelangsungan hidup suatu negara, ia harus mengejar kepentingan nasionalnya. Negara harus stabil dan mandiri. Inilah jenis prioritas nasional yang dapat mempengaruhi jalannya perumusan politik. Sebab, sesungguhnya politik lahir dan dibentuk oleh motif-motif profit.

Saat ini, Indonesia memiliki banyak sekali partai politik yang masing-masing memiliki dasar ideologi politik yang berbeda untuk menggalang dukungan dan suara. Filosofi ini akan diperdebatkan dalam partai demokrasi (Prianto, 2016). Karena dinamika yang ada di industri, mayoritas pihak terjebak dalam arena persaingan. Merupakan kepentingan partai untuk berkembang, sehingga partai tersebut dapat menarik simpati publik, dipilih oleh mayoritas pemilih, dan merebut kekuasaan. Memperoleh keseimbangan antara dukungan publik dan tetap berkuasa di masa depan akan menjadi tujuan dan kepentingan strategis. Saat berpartisipasi dalam media berita semata-mata untuk mempromosikan kebijakan partai, diskusikan politik untuk kebaikan orang, komunitas, atau kelompok. Demikian pula, kelompok politik lain yang berlomba-lomba mendapatkan simpati (Prasetya, 2011).

Jika hal ini tidak ditangani, para pemimpin di negara ini akan beralih ke Machiavellist, yang menganut prinsip politik tanpa memperhatikan integritas. Politik Hanya Memperhatikan cara memperoleh dan mempertahankan kendali. Jika dominasi menjadi pedoman dalam pemerintahan, maka politik penuh dengan konflik. Karena beberapa kepentingan bertabrakan, kepentingan bersaing untuk mendapatkan pengaruh. Hal ini secara tegas tidak konsisten dengan tujuan nasional, termasuk untuk politik bersama (Rosana, 2012)

Adanya budaya oligarki partai politik yang diartikan sebagai kecenderungan sebuah partai politik lebih memprioritaskan kebutuhan pengelolaannya di atas kepentingan masyarakat umum. Potensi negatif Oligarki dapat dimitigasi dengan berbagai mekanisme, termasuk pendukung internal yang mempromosikan demokratisasi melalui keterlibatan individu yang tumbuh dalam pengambilan keputusan partai (Haris, 2005). Ini harus diformalkan dalam AD/ART; jika tidak, lhal ini akan menjadi aturan hukum yang berfungsi sebagai rutinitas. Seiring dengan anggaran dasar dan anggaran rumah tangga partai, diperlukan kode etik organisasi internal yang baru, yang akan memandu semua anggota dalam menangani perselisihan antar partai secara demokratis. Dimulai dengan wahana pengungkapan diri oleh individu di luar koalisi tentang tingkat antusiasme mereka terhadap kebijakan partai politik. Kehadiran dewan harus mampu memajukan tujuan dan keinginan konstituennya. Dalam situasi ini, posisi negara sangat penting dalam memelihara lingkungan 
politik yang stabil. Melalui pembentukan pemerintahan yang jujur dan profesional, peluang elit partai politik untuk menyalahgunakan pengaruh mereka untuk keuntungan pribadi akan berkurang. Ini berpotensi untuk bekerja dengan baik jika didukung oleh media. Kesetaraan pers, profesionalisme pers, dan komitmen untuk menginformasikan kepada masyarakat luas akan menjadi respon pers terhadap sikap atau strategi yang diadopsi oleh pembuat kebijakan internal partai politik.

\section{b. Hambatan Birokrasi}

Mempertahankan implementasi reformasi birokrasi sangat penting untuk mencapai tata kelola pemerintahan yang baik. Hasil dari fase perubahan birokrasi 2010-2014 menjadi fondasi untuk tingkat reformasi berikutnya (2015-2019). Dengan demikian, reformasi birokrasi 2015-2019 merupakan hasil dari tahapan reformasi birokrasi sebelumnya. Berbagai langkah tersebut dirinci dalam Road Map yang akan dikembangkan oleh berbagai instansi. Penguatan meliputi penguatan/pemutakhiran kondisi yang menguntungkan secara terus menerus, memelihara perubahan, mengenali dan menyelesaikan tantangan, serta memperluas jangkauan pelaksanaan reformasi birokrasi.

Dampak terhadap penyelenggaraan pemerintahan terbelah pasca Pemilihan Gubernur Kalimantan Barat 2018 melalui hasil analisis menggunakan teori berdasarkan driven theory Kepemimpinan visioner dari Nanus (1992) menjawab rumusan permasalahan kedua adalah sebagai berikut: Terkait dengan hambatan politik, dan Hambatan Birokrasi Terhadap penyelenggaraan Pemerintahan Terbelah Pasca Pemilihan Gubernur Kalimantan Barat 2018, Gubernur dan Wakil Gubernur Provinsi Kalimantan Barat dalam pengambilan keputusan akan ditentukan oleh sistem politik di Indonesia. Bergantung pada kekuasaan yang ada pada jabatannya dan pentingnya konsensus politik dan masyarakat di di Provinsi Kalimantan Barat. Faktor lain seperti rasionalitas, kepribadian, organisasi juga berpengaruh pada kepala Daerah dalam mengmabil keputusan. Namun keputusan tersebut juga dapat dikompromikan oleh lingkungan politik, tergantung pada jenis sistem yang dipraktikkan. Dalam penelitian ini, peneliti menemukan dampak lingkungan politik pada pengambilan keputusan pemimpin, mengingat pemimpin dalam sistem politik yang berbeda. Lingkungan politik menjadi faktor terpenting yang mempengaruhi pengambilan keputusan, peneliti menganalisis faktor-faktor seperti kekuasaan yang ada pada kepala pemerintahan, kesepakatan yang jelas, komitmen politik, pengambilan keputusan strategis, kepribadian pemimpin, rasionalitas, dan dampak kelompok kepentingan. Elemen penting dari lingkungan eksternal yang mempengaruhi kepala pemerintahan termasuk pelobi politik, yudikatif, dan sektor pengusaha. Organisasi Non-pemerintah dan Organisasi Antar pemerintah daerah juga memiliki pengaruh atas pengambilan keputusan kebijakan oleh kepala daerah. Dalam demokrasi modern, birokrasi seharusnya tetap netral secara politik dan memastikan bahwa keputusan pemerintah dilaksanakan. Kenyataannya, hubungan birokrat dan pemimpin politik tidak selalu jelas. Selain itu, desain kelembagaan birokrasi dapat sangat mempengaruhi kebijakan pemerintah pusat. Sumber daya manusia birokrasi tidak diragukan lagi adalah keahliannya. Ini memilih informasi yang disajikan kepada Gubernur dan Wakil Gubernur Provinsi Kalimantan Barat dan mengaturnya secara cerdas. Dengan menyajikan masalah atau tindakan yang mungkin dilakukan dengan cara tertentu, itu menyusun pengambilan keputusan para pemimpin. kebutuhan organisasi maupun kepentingan birokrasi bukanlah penentu kebijakan yang 
fundamental. Batasan yang diberlakukan sesuai standar operasi prosedur serta arah kebijakan merupakan fungsi dari nilai-nilai pengambil keputusan.

Kenyataan dilapangan bahwa birokrasi memiliki tujuan yang tidak sejalan dengan Gubernur dan Wakil Gubernur terpilih; seringkali yang bertentangan dalam organisasi pemerintah adalah keyakinan tentang bagaimana mencapai tujuan tersebut. Lebih jauh lagi, tidak dapat dimengerti mengapa Gubernur dan Wakil Gubernur terpilih dengan segenap kekuasaannya harus melakukan tawar-menawar dengan pejabat lain dalam menjalankan roda pemerintahan. Lebih lanjut posisi birokrasi dapat mempengaruhi proses pengambilan keputusan. posisi menentukan kekuatan birokrasi tetapi pada saat yang sama salah satu aspek fundamental dalam proses tawar-menawar adalah kapabilitas dari birokrat tersebut, Gubernur dan Wakil Gubernur terpilih harus memiliki kecerdasan, komunikasi networking yang baik ,mengamalkan dan menjalankan nilai demokrasi secara benar untuk kepentingan masyarakat dan melakukan inovasi inovasi untuk mencapai tujuan mewujudkan pemerintahan yang baik dan benar ,Inilah yang menjadi temuan peneliti yang akan peneliti jelaskan dalam temuan peneliti Model "ANDI" terhadap implikasi teoritik.

\section{Teoritik Temuan Peneliti Model "ANDI"}

Dalam menjawab pertanyaan penelitian dalam Menemukan Model Baru Terhadap penyelenggaraan Pemerintahan Terbelah Pasca Pemilihan Gubernur Kalimantan Barat 2018 Terkait uraian diatas, dalam melakukan penelitian ini peneliti menemukan beberapa temuan setelah melakukan beberapa wawancara secara mendalam dengan Narasumber. Hal tersebut menjadi inspirasi bagi peneliti untuk menggambarkan model yang tepat bagi kepemimpinan terbelah di Provinsi Kalimantan Barat. Adapaun Model Penelitian yang di rumuskan oleh Peneliti tentang model Model "ANDI" yang maknanya A (Agility), N (Networking), D (Demokrasi), I (Inovasi) dapat dijabarkan dalam argumen peneliti sebagai berikut:

a. Agility (Kecerdasan)

Kecerdasan untuk mengembangkan budaya saling berkoordinasi dan berkomunikasi secara terpadu dan harmonis, dan kecerdasan untuk meningkatkan budaya kerja aparatur pelaksana kebijakan, untuk menjawab tantangan tersebut dalam membangun Implementasi Teoretis dapat di jelaskan bahwa sebuah proses Demokrasi tingkat daerah dimulai dari Pemilihan Kepala Daerah di Provinsi Kalimantan Barat.

Rincian yang ditemukan di lapangan menunjukkan adanya bahaya yang terkait dengan penyelenggaraan Pilkada yang akan berdampak signifikan terhadap kehidupan sosial ekonomi masyarakat. Secara spesifik, Pilkada yang tidak dilaksanakan secara optimal akan menimbulkan perselisihan antar berbagai pihak, membangun lingkungan yang tidak menguntungkan, tidak stabil, dan akan menghambat proses politik dan ekonomi lokal. Dalam arti kepemimpinan Provinsi Kalimantan Barat dalam membangun masyarakat pasca-pilkada, konfrontasi dengan tindakan anarkisme massa dapat mempengaruhi keputusan, kemajuan, dan menghambat penolakan terhadap ekonomi lokal, yang merupakan penduduk yang lemah dan tidak berdaya.

b. Networking (Penguatan jaringan politik dan Birokrasi)

Fakta dilapangan bahwa untuk menghindari kepemimpinan terbelah, Gubernur dan Wakil Gubernur Kalimantan Barat harus mengkombinasikan teori-teori dasar kepemimpinan dengan kearifan lokal. jaringan kinerja sosial, Hal tersebut karena Kalimantan Barat 
memiliki karakteristik sosial yang unik. Jadi secara De Facto, ada beberapa hal yang harus di sesuaikan, diadaptasikan dengan karakter sosial dan budaya masyarakat Kalimantan Barat. Dalam organisasi politik kadang memiliki aturan yang tidak tertulis. Aturan-aturan ini adalah apa yang telah disepakati para anggota organisasi sebagai kerangka kerja bagaimana organisasi akan menangani konflik politik. Namun, aturan juga dapat berubah dan kadangkadang faktor situasional lebih dominan ketika terjadi di lapangan. Diperlukan jaringan kinerja kelembagaan membangun aliansi dengan banyak pihak. Gubernur dan Wakil Gubernur Kalimantan Barat perlu membangun aliansi jauh sebelum konflik politik. Aliansi adalah cara terbaik untuk saling membantu memastikan tidak ada yang melewati radar politik kolektif Gubernur dan Wakil Gubernur Kalimantan Barat dalam memimpin pemerintahan. Membina hubungan: Wawasan pribadi terhadap stakeholder dapat membantu Gubernur dan Wakil Gubernur Kalimantan Barat menavigasi lanskap politik dengan memberi Gubernur dan Wakil Gubernur Kalimantan Barat konten ke dalam kepribadian mereka. Ini berguna dalam menghindari kepemimpinan terbelah. Ketika Gubernur dan Wakil Gubernur Kalimantan Barat benar, biarkan stakeholder mengetahui fakta yang sebenarnya. Jangan tertekan saat ada pihak yang menyerang Gubernur dan Wakil Gubernur Kalimantan Barat. Sebaliknya, nyatakan fakta yang benar dan bangga bagaimana Gubernur dan Wakil Gubernur Kalimantan Barat menangani situasi tersebut (jaringan kinerja administrasi).

\section{c. Demokrasi}

Memahami apa itu demokrasi memungkinkan seseorang untuk lebih memahami struktur politik yang berfungsi. Berikut adalah beberapa kesepakatan yang dicapai antara Gubernur Kalbar dan Wakil Gubernur serta para pemangku kepentingan yang akan membantu Gubernur dan Wakil Gubernur dalam menghindari kepemimpinan yang terbagi:

1) Berdasarkan data: dalam lingkup pemerintahan, data mengalahkan segala jenis agenda politik. Ketika Gubernur dan Wakil Gubernur Kalimantan Barat didorong oleh data, maka Gubernur dan Wakil Gubernur Kalimantan Barat mengandalkan fakta dan itulah metode terbaik untuk menghindari kepemimpinan terbelah. Apabila Gubernur dan Wakil Gubernur Kalimantan Barat salah, sebaiknya mengakui kesalahn tersebut: Ketika Gubernur dan Wakil Gubernur membuat kesalahan, maka akan jarang terjadi mereka mengakui kesalahan tersebut. Namun ketika mereka mengakui kesalahan tersebut maka hal tersebut akan meredakan situasi yang bermuatan politik dalam sekejap.

2) Memahami Permasalahan: Dalam lingkungan yang bermuatan politik, permasalahan yang terjadi akan mengarah pada pimpinan politik. Mengetahui permasalahan yang terjadi akan memungkinkan Gubernur dan Wakil Gubernur Kalimantan Barat mengantisipasi hal ini dan menyesuaikannya.

3) Informasi yang sebenarnya: pada kenyataannya kebanyakan orang akan menutupi informasi kebenaran karena itu mungkin membuat mereka terlihat buruk. Jangan terlalu khawatir tentang terlihat buruk itu, tetapi pastikan Gubernur dan Wakil Gubernur Kalimantan Barat memiliki fakta yang benar dan Gubernur dan Wakil Gubernur Kalimantan Barat berusaha untuk mencari kebenaran tentang situasi tersebut. Selalu perhatikan kepentingan terbaik bagi Provinsi Kalimantan Barat.

4) Membantu Masyarakat: Dengan membantu orang lain, Gubernur dan Wakil Gubernur Kalimantan Barat mendapatkan kepercayaan dan rasa hormat mereka. 
Gubernur dan Wakil Gubernur Kalimantan Barat juga mendapatkan rasa terima kasih mereka yang akan berguna ketika Gubernur dan Wakil Gubernur Kalimantan Barat membutuhkan bantuan dan support dari masyarakat dalam menjalankan pemerintahan.

5) Temukan kesamaan persepsi: Kesamaan adalah di mana semua orang dalam situasi tersebut dapat setuju. Dalam hampir setiap situasi, ada beberapa titik umum di mana semua pihak akan setuju. Menemukan itu akan memungkinkan Gubernur dan Wakil Gubernur Kalimantan Barat untuk mencapai langkah politik kritis seperti meminta para pihak yang terlibat baik itu Eksekutif, Legislatif, dan Yudikatif untuk menyetujui sesuatu.Setuju untuk tidak setuju: Kadang-kadang situasi akan menjadi kekacauan sehingga satu-satunya solusi adalah setuju untuk tidak setuju. Ini harus menjadi alternatif terakhir Gubernur dan Wakil Gubernur Kalimantan Barat tetapi ini merupakan alat yang ampuh ketika Gubernur dan Wakil Gubernur Kalimantan Barat menemui jalan buntu.

d. Inovasi

Dalam berkomitmen pada inovasi organisasi dengan pencapaian layanan Pemerintah Daerah. Keberhasilan Gubernur dan Wakil Gubernur Kalbar merupakan fakta empiris yang bisa dipahami dan disaksikan. Penilaian kinerja difokuskan pada model kompetensi yang mengutamakan keterampilan Gubernur dan Wakil Gubernur Kalimantan Barat saat ini dan potensialnya. Hasil Gubernur dan Wakil Gubernur Kalimantan Barat, yang meliputi kinerja misi dan kinerja non-tugas (kinerja non-tugas atau kinerja kontekstual). Di luar masa jabatan, kegiatan kepemimpinan Gubernur dan Wakil Gubernur Kalbar menjadi ciri khas dari praktik kepemimpinan masing-masing..

Perilaku kepemimpinan ini berada di luar persyaratan formal dalam pekerjaan mereka, bersifat bebas dan tidak secara eksplisit berada dalam prosedur kerja dan sistem yang ada. Keterikatan Gubernur dan Wakil Gubernur pada kegiatan yang dilakukan secara sukarela sangat penting bagi kinerja dan keefektifan organisasi yang dipimpinnya. Ketika calon Gubernur dan Wakil Gubernur Kalimantan Barat telah memenuhi segala persyaratan menjadi gubernur dan wakil gubernur dan kemudian mereka terpilih, maka mereka harus siap dengan segala resiko dalam rangka menjabat dan menjalankan tugas dari jabatan tersebut.

Kapasitas administrasi Gubernur dan Wakil Gubernur menjadi salah satu alasan yang berkontribusi terhadap pertumbuhan daerah yang dipimpinnya. Gubernur dan Wakil Gubernur yang aktif dalam merancang struktur bisnis yang efektif dan membuat pilihan yang memberi nilai tambah bagi daerah yang dipimpinnya merupakan faktor penentu. Gubernur dan Wakil Gubernur wajib menyampaikan keberhasilan penyelenggaraannya kepada seluruh pemangku kepentingan perusahaan melalui laporan transparansi yang disiapkan untuk setiap siklus pelaporan. Gubernur dan Wakil Gubernur harus memiliki keterampilan administratif yang memadai untuk secara efektif mengoordinasikan bidang-bidang yang menjadi tanggung jawab mereka. Dalam menjalankan tugasnya, baik Gubernur maupun Wakil Gubernur berpedoman pada standar perilaku profesional tertentu atau kode etik yang tersirat, sehingga setiap keputusan yang diambil harus mewakili pertimbangan profesional pemerintah daerah dalam melayani kota, bukan sarat keputusan. dengan teknik yang bertujuan membantu. pesta mereka. Gubernur dan Wakil Gubernur harus didukung oleh budaya perusahaan yang menghargai pengambilan keputusan yang bertanggung jawab, dan pemerintah kota yang 
mereka layani harus memiliki insentif untuk tetap tulus mewakili masyarakat. Jika ini dilakukan, kepemimpinan Provinsi Kalimantan Barat yang terfragmentasi bisa dihentikan.

\section{KESIMPULAN}

Dampak Terhadap penyelenggaraan Pemerintahan Terbelah Pasca Pemilihan Gubernur Kalimantan Barat 2018 Terkait dengan hambatan politik, dan Hambatan Birokrasi Terhadap penyelenggaraan Pemerintahan Terbelah Pasca Pemilihan Gubernur Kalimantan Barat 2018, Gubernur dan Wakil Gubernur Provinsi Kalimantan Barat dalam pengambilan keputusan akan ditentukan oleh sistem politik di Indonesia. Bergantung pada kekuasaan yang ada pada jabatannya dan pentingnya konsensus politik dan masyarakat di di Provinsi Kalimantan Barat. Faktor lain seperti rasionalitas, kepribadian, organisasi juga berpengaruh pada kepala Daerah dalam mengmabil keputusan.

Temuan peneliti Model "ANDI" terhadap penyelenggaraan pemerintahan terbelah pasca Pemilihan Gubernur Kalimantan Barat 2018 yang maknanya A (Agility), N (Networking), D (Demokrasi), I (Inovasi) dapat dijabarkan dan diartikan oleh peneliti sebagai berikut: Kecerdasan dalam penguatan jaringan politik dan birokrasi dalam mencapai tujuan Berdemokrasi perlu dilakukan sebuah Inovasi baru yaitu Gubernur dan Wakil Gubernur dalam memimpin harus menyesuaikan kultur organisasional pemerintahan Provinsi Kalimantan Barat dalam pengambilan keputusan dan selalu bertindak jujur dalam melayani masyarakat.

\section{DAFTAR PUSTAKA}

Hofman, B., Kaiser, K., \& Goga, S. (2002). Decentralizing Indonesia-Regional Public Expenditure Review: Overview Report. World Bank. Washington DC.

Dewanta, A. S. (2016). Otonomi dan Pembangunan Daerah. UNISIA, (53), 325-329.

Maryam, S. N. (2017). Mewujudkan Good Governance Melalui Pelayanan Publik. JIPSIJurnal Ilmu Politik Dan Komunikasi UNIKOM, 6.

Prasojo, E. (2003). Problem dan Perpektif Desentralisasi Politik di Indonesia harkat bangsa, Dalam Otonomi Daerah Evaluasi Dan Perpektif Patnership, Jakarta: Yayasan Rimba Persada.

Pardede, M. (2014). Implikasi Sistem Pemilihan Umum Indonesia. Jurnal Rechts Vinding: Media Pembinaan Hukum Nasional, 3(1), 85-99.

Setiawan, R., Samin, R., \& Mahadiansar, M. (2018). Dampak Desentralisasi terhadap Kapabilitas Kepala Daerah (Studi Kasus Gubernur Riau Periode Tahun 20082013). Jurnal Ilmu Administrasi Negara (JUAN), 6(2), 15-24.

Sulaiman, B. H. (2020). Pola Hubungan Eksekutif Dan Legislatif Dalam Penyelenggaraan Otsus di Daerah. Jurnal Geuthèe: Penelitian Multidisiplin, 3(2), 487-499.

Solihah, R., \& Witianti, S. (2016). Pelaksanaan Fungsi Legislasi Dewan Perwakilan Rakyat Pasca Pemilu 2014: Permasalahan dan Upaya Mengatasinya. Cosmogov: Jurnal Ilmu Pemerintahan, 2(2), 291-307.

Elgie, R. (2001). Divided Government In Comparative Perspective. Oxford: Oxford University Press. 
Howell, W., Adler, S., Cameron, C., \& Riemann, C. (2000). Divided Government, And the Legislative Productivity of Congress, 1945-94. Legislative Studies Quarterly, 285312.

Permata, A. N. (2008). Islamist Party And Democratic Participation: Prosperous Justice Party (PKS) In Indonesia 1998-2006 (Doctoral dissertation, Université de Münster).

Saraswati, R. (2010). Aplikasi Calon Perseorangan Sebagai Kepala Daerah Dalam Penyelenggaraan Pemerintahan Di Daerah. Masalah-Masalah Hukum, 39(4), 359-365

Vermonte, P. (2015). Indonesia's 2014 Elections: Practical Innovations and Optimistic Outcomes. Asian Politics \& Policy, 7(2), 303-312.

Creswell, J. W. (2002). Desain penelitian. Pendekatan Kualitatif \& Kuantitatif, Jakarta: KIK.

Denzin, N. K., \& Lincoln, Y. S. (2005). Introduction: The discipline and practice of qualitative research.Psycnet.

Fuadi, S. H. (2020). Resolusi Konflik Sosial Perspektif Hukum Islam dan Hukum Adat pada Pemilihan Kepala Desa Bajang Mlarak Ponorogo. AL-MANHAJ: Jurnal Hukum dan Pranata Sosial Islam, 2(1), 86-111.

Dewantara, A. W. (2017). Kerasulan Awam di Bidang Politik (Sosial-Kemasyarakatan), Dan Relevansinya Bagi Multikulturalisme Indonesia. JPAK: Jurnal Pendidikan Agama Katolik, 18(9), 3-15.

Prianto, B. (2016). Partai Politik, Fenomena Dinasti Politik dalam Pemilihan Kepala Daerah, dan Desentralisasi. Publisia: Jurnal Ilmu Administrasi Publik, 1(2).

Prasetya, I. Y. (2011). Pergeseran Peran Ideologi Dalam Partai Politik. Jurnal Ilmu Politik dan Ilmu Pemerintahan, 1(1), 30-40.

Rosana, E. (2012). Partai Politik dan Pembangunan Politik. Jurnal Tapis: Jurnal Teropong Aspirasi Politik Islam, 8(1), 135-150.

Haris, S. (2005). Pemilu langsung di tengah oligarki partai: proses nominasi dan seleksi calon legislatif Pemilu 2004. Jakarta: Gramedia Pustaka Utama. 